\title{
Food habits of Rhinella proboscidea (Anura: Bufonidae) in terra firme forests of central Amazonia
}

\author{
Alice Cristina Rodrigues Borges, ${ }^{1}$ Talitha Ferreira dos Santos, ${ }^{2}$ Luciana Frazão, ${ }^{3}$ Sergio \\ Marques-Souza, ${ }^{4}$ and Marcelo Menin ${ }^{1,5}$ \\ ${ }^{1}$ Coleção Zoológica Prof. Paulo Bührnheim, Instituto de Ciências Biológicas, Universidade Federal do Amazonas. Avenida \\ General Rodrigo Otávio Jordão Ramos 6200, 69077-000, Manaus, AM, Brazil. \\ 2 Programa de Pós-Graduação em Entomologia, Instituto Nacional de Pesquisas da Amazônia. Avenida André Araújo 2936, \\ 69060-001, Manaus, AM, Brazil. \\ ${ }^{3}$ Programa de Pós-Graduação em Biodiversidade e Biotecnologia da Amazônia Legal, BIONORTE, Universidade do Estado \\ do Amazonas. Avenida Carvalho Leal 177, 69065-001, Manaus, AM, Brazil. \\ ${ }^{4}$ Departamento de Zoologia, Instituto de Biociências, Universidade de São Paulo. Rua do Matão 321, Travessa 14, 05508-090, \\ São Paulo, SP, Brazil. \\ ${ }^{5}$ Departamento de Biologia and Programa de Pós-Graduação em Zoologia, Instituto de Ciências Biológicas, Universidade \\ Federal do Amazonas. Avenida General Rodrigo Otávio Jordão Ramos 6200, 69077-000, Manaus, AM, Brazil. \\ E-mail: menin@ufam.edu.br.
}

\begin{abstract}
Food habits of Rhinella proboscidea (Anura: Bufonidae) in terra firme forests of central Amazonia. Anuran species are considered generalist and opportunist feeders. However, some species have dietary specializations. Here we describe the diet composition of Rhinella proboscidea based on the stomach content of 29 individuals captured in terra firme forests in Manaus and São Sebastião do Uatumã, state of Amazonas, Brazil. Each prey item was measured and identified to Order, Suborder or Family; ants were identified to Genus. We determined and tested for differences in the trophic niche breadth and the relationships between the frog size and the volume of the largest prey item. We recorded 1614 prey items of 44 taxa. Hymenoptera was the most abundant Order followed by Isoptera, Acari, Coleoptera, Orthoptera, Araneae, Hemiptera, Dermaptera, Diptera, and Collembola. Formicidae comprised $46.56 \%$ of the all stomach items and was represented by six subfamilies and 22 genera. Additionally, we found 80 nematodes in a total of 18 frogs. There was a significant difference in the trophic niche breadths of the study areas, and a positive relationship between the toad size and volume of the largest prey item consumed. Rhinella proboscidea feeds on a variety of invertebrates, with ants, termites, and mites being the most abundant; this suggests that the toad is an active forager. The most common subfamily was Myrmicinae primarily represented by Crematogaster and Atta. Differences in trophic niche breadths of the study areas may be related to seasonal differences in the diet composition or local factors.
\end{abstract}

Keywords: amphibians, diet composition, Formicidae, northern Brazil.

Received 21 September 2018

Accepted 20 February 2019

Distributed June 2019 


\begin{abstract}
Resumo
Hábito alimentar de Rhinella proboscidea (Anura: Bufonidae) em florestas de terra firme da Amazônia Central. Os anuros são considerados predadores generalistas e oportunistas, mas algumas espécies apresentam especialização na dieta. Neste estudo descrevemos a composição da dieta de Rhinella proboscidea baseada no conteúdo estomacal de 29 indivíduos coletados em florestas de terra firme de Manaus e São Sebastião do Uatumã, estado do Amazonas, Brasil. Cada item encontrado foi medido e identificado até o nível de Ordem, Subordem ou Família; as formigas foram identificadas até gênero. Determinamos e testamos a diferença na amplitude do nicho trófico e a relação entre o tamanho dos anuros e o volume da maior presa consumida. Encontramos 1.614 presas pertencentes a 44 categorias taxonômicas. Hymenoptera foi a Ordem mais abundante seguida por Isoptera, Acari, Coleoptera, Orthoptera, Araneae, Hemiptera, Dermaptera, Diptera e Collembola. Formicidae abrangeu 46,56\% do total de itens encontrados nos estômagos e foi representada por seis subfamílias e 22 gêneros. Adicionalmente, encontramos 80 nematoides nos estômagos de 18 anuros. Houve diferença significativa na amplitude do nicho trófico entre as áreas de estudo e uma relação positiva entre o tamanho dos anuros e o volume das maiores presas consumidas. Rhinella proboscidea alimenta-se de alguns grupos de invertebrados, e formigas, cupins e ácaros são os itens mais abundantes, sugerindo que essa espécie é uma forrageadora ativa. A subfamília mais comum foi Myrmicinae, representada pelos gêneros Crematogaster e Atta. As diferenças no nicho trófico da espécie entre as áreas estudadas podem estar relacionadas com diferenças sazonais na composição da dieta ou a fatores locais.
\end{abstract}

Palavras-chave: anfíbios, composição da dieta, Formicidae, norte do Brasil.

\section{Introduction}

Bufonids, like other anurans, are considered to be feeding generalists that consume a great variety of prey (Duellman and Trueb 1994) mainly insects and arachnids (Parmelee 1999, Batista et al. 2011). However, studies have reported some dietary specialization in bufonids (Toft 1980, 1981) that feed preferentially on ants (Isacch and Barg 2002, Solé et al. 2017). Rhinella proboscidea (Spix, 1824) is a mediumsized anuran found in terra firme (unflooded) forests (Lima et al. 2012) along the Amazon River ranging from Peru to the city of Manaus, Brazil (Frost 2019). It is a member of the Rhinella margaritifera species group (Frost 2019). Individuals are terrestrial, diurnal, and live in the leaf litter of forests (Lima et al. 2012). Lima (1998; as Bufo cf. typhonius) and Lima and Magnuson (1998) showed that in central Amazonia, small individuals of $R$. proboscidea fed largely on mites, whereas adults fed largely on ants and the prey types choice is independent of the prey size. Herein, we provide a detailed description of the composition of the diet of $R$. proboscidea from terra firme forests of central Amazonia, Brazil.

\section{Materials and Methods}

We examined 29 Rhinella proboscidea that are deposited in the Amphibia Section of the Paulo Bührnheim Zoological Collection of the Universidade Federal do Amazonas, Manaus, Amazonas, Brazil (CZPB-AA 006-020, CZPBAA 438, and CZPB-AA 476-488). The toads were euthanized $2-5 \mathrm{hr}$ after collection with an overdose of $2 \%$ lidocaine hydrochloride, fixed in $10 \%$ formalin, and preserved in $70 \%$ alcohol. The specimens were collected in the following areas: (1) municipality of Manaus, state of Amazonas, Brazil, in the Adolpho Ducke Forest Reserve (13 females captured in June 2001, between $02^{\circ} 55^{\prime}$ and $03^{\circ} 01^{\prime} \mathrm{S}$ and between $59^{\circ} 53^{\prime}$ and 59 59' W) and the Experimental Farm of the Universidade Federal do Amazonas (1 female captured in June 2011, between $02^{\circ} 37^{\prime} 17^{\prime \prime}$ and $02^{\circ} 39^{\prime} 41^{\prime \prime} \mathrm{S}$ and between $60^{\circ} 03^{\prime} 29^{\prime \prime}$ and 
$60^{\circ} 07^{\prime} 57^{\prime \prime} \mathrm{W}$ ); and (2) two forest sites located on opposite margins of the Jatapú River (15 specimens -5 males, 4 females and 6 juvenilescaptured in September 2011, left margin at $01^{\circ} 55^{\prime} 53^{\prime \prime} \mathrm{S}$ and $58^{\circ} 15^{\prime} 21^{\prime \prime} \mathrm{W}$; right margin at $02^{\circ} 01^{\prime} 31^{\prime \prime} \mathrm{S}$ and $58^{\circ} 11^{\prime} 24^{\prime \prime} \mathrm{W}$ ) at the municipality of São Sebastião do Uatumã, state of Amazonas, Brazil. The Adolpho Ducke Forest Reserve has an area of 10,000 ha, whereas the Experimental Farm of the Universidade Federal do Amazonas is 3000 ha. Both locations include the terra firme habitat with a well-drained forest that does not flood seasonally and that has a closed canopy, emergent trees, and abundant sessile palms. The sites along the Jatapú River contain terra firme forests with tall canopy and an abundance of palms, seasonally flooded meadows and patches of dense campina forest (Oliveira et al. 2014). All sampling sites have a tropical monsoon climate without a dry season (Peel et al. 2007), a rainy season lasting from November-May and a mean annual temperature of approximately $26^{\circ} \mathrm{C}$ (Marques-Filho et al. 1981).

The stomach contents were identified to order, suborder or family, following the identification keys of Triplehorn and Johnson (2011) and Rafael et al. (2012). The ant genera were determined based on Baccaro et al. (2015). We measured the length and width of each prey item with an ocular micrometer connected to a Zeiss Stemi SV 11 stereomicroscope. The volume of each item was estimated using the ellipsoid formula defined by Dunham (1983): $V=(4 \pi / 3)($ length $/ 2)(\text { width } / 2)^{2}$. We also calculated the index of relative importance (IRI; Pinkas et al. 1971) to each prey category and each study area with the formula IRI $=(\% N+\% \mathrm{~V}) \% F$, where $\% N$ is the numerical percentage, $\% \mathrm{~V}$ is the volumetric percentage, and $\% F$ is the frequency of occurrence percentage (percentage of occurrence of each prey category in relation to the total samples). The trophic niche breadths in both sites (Manaus and Jatapú River) were determined using the Shannon-Wiener diversity index $\left(\mathrm{H}^{\prime}\right)$ (Krebs 1999). The values of this index were compared by means of a Student's t-test (Zar
2010). We also measured the snout-vent lengths (SVL) of the toads with digital callipers and used Spearman's correlation coefficient to evaluate correlations between the volume of the largest prey in the stomach content and the SVL. This analysis was performed for the two areas combined because of the small sample sizes. The software Systat 12.0 was utilized for statistical and graphical analysis.

\section{Results}

A total of 1614 prey items were found in the stomach of 27 toads from both study areas; two individuals (14.3\%) from Manaus had empty stomachs. The prey items represent 44 taxa, with Manaus having 899 prey of 23 taxa and the Jatapú River having 715 prey of 39 taxa (Table 1). The number of prey items per stomach varied from 2-336 items (mean $=59.78 \pm 99.89)$ and the number of prey taxa from 1-12. Of the orders, Hymenoptera was the most abundant (750 individuals), followed by Isoptera (511 individuals), Acari (290), Coleoptera (25), Orthoptera (17), Araneae (12), Hemiptera (5), Dermaptera (2), Diptera (1), and Collembola (1). Formicidae (745 individuals of 6 subfamiliesDorylinae, Dolichoderinae, Ectatomminae, Formicinae, Myrmicinae, and Ponerinae-and 22 genera) represented $46.56 \%$ of the stomach items. Myrmicinae was the most abundant subfamily and Crematogaster the most abundant genus, both in Manaus and Jatapú. Additionally, 80 nematodes (Phylum Nematoda) were found in $18(58.06 \%)$ toads, which had from 1-14 nematodes per stomach. Plant material was found in $25.8 \%$ of the stomachs, whereas sand grains and silt were present in $6.45 \%$ of the stomachs.

The frequency and volume of prey items in each sampling site are listed in Table 1 and are discussed in descending order of importance below. In Manaus toads, the most frequently encountered prey were Araneae, Coleoptera of the family Curculionidae, and unidentified and Formicidae/Ectatomminae of the genus 
Borges et al.

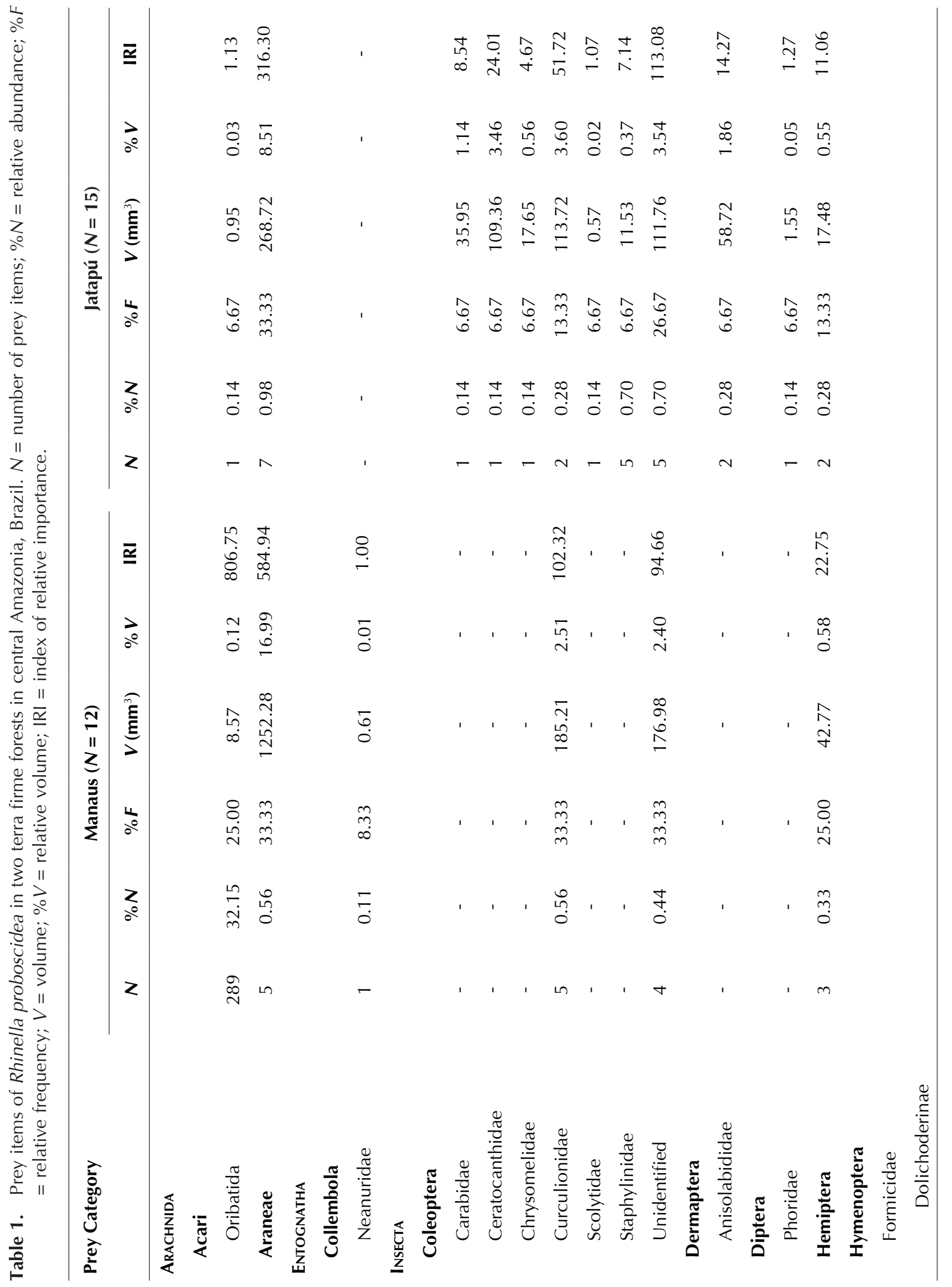




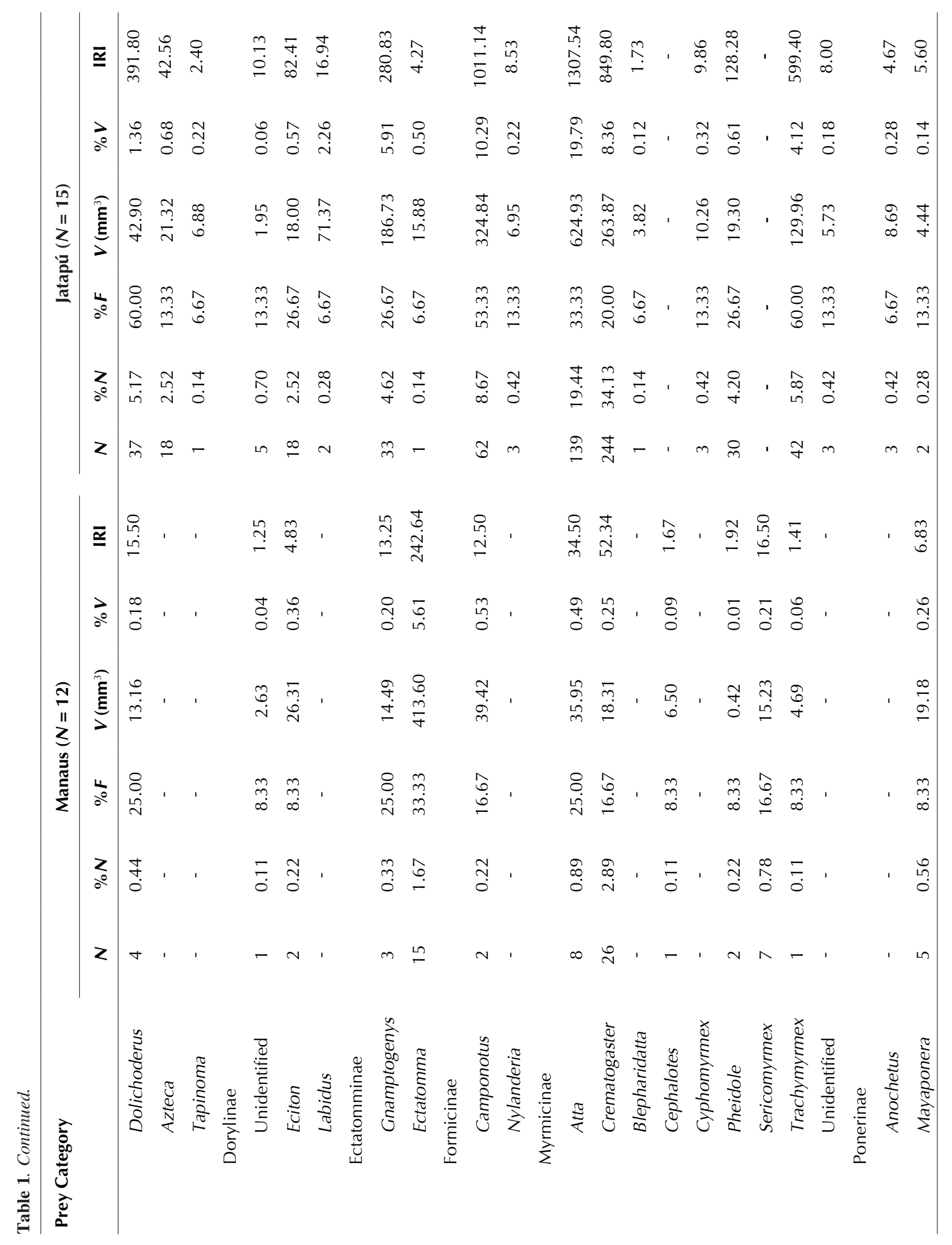




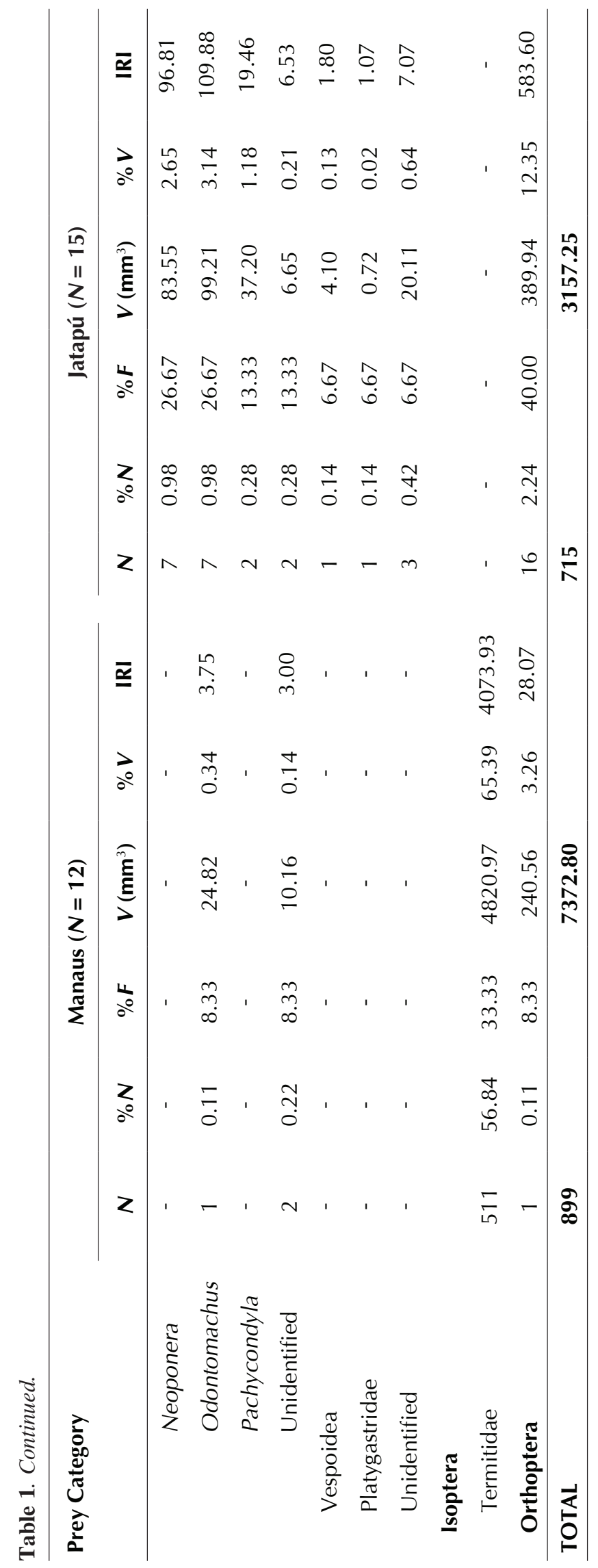

Ectatomma; volumetrically, the most important items were Isoptera, Termitidae, Araneae, Formicidae/Ectatomminae of the genus Ectatomma, and Orthoptera. At the Jatapú River sites, Formicidae/Dolichoderinae of the genus Dolichoderus, Myrmicinae of the genus Trachymyrmex, Formicinae of the genus Camponotus and Orthoptera were the frequent prey items; Formicidae/Myrmicinae of the genus Atta, Orthoptera, Formicinae of the genus Camponotus, and Araneae were the most important volumetrically. Based on the index of relative importance, the most important prey items for the specimens collected in Manaus were Isoptera Termitidae, Acari/Oribatida, Araneae, Formicidae/Ectatominae of the genus Ectatomma, and Coleoptera of the family Curculionidae (Table 1). For the specimens collected in the Jatapú River, the most important prey categories were Formicidae/Myrmicinae of the genus Atta, Formicinae of the genus Camponotus, Myrmicinae of the genera Crematogaster and Trachymyrmex, and Orthoptera (Table 1). The trophic niche breadth was significantly $(t=-16.62, d f=1862, p<$ $0.001)$ greater in the Jatapú River $\left(H^{\prime}=1.01\right)$ than Manaus $\left(H^{\prime}=0.52\right)$. We found a positive relationship between the SVL of the toads and the respective size of the largest prey item consumed ( $r=0.656, p<0.001$, Figure 1$)$. The SVLs of the individuals of Rhinella proboscidea from Jatapú varied from 20.06-48.27 mm (mean $=36.11 \pm 9.93$ ), those of the specimens from Manaus varied from $56.32-59.10 \mathrm{~mm}$ (mean = $51.31 \pm 4.31$ ). The volume of the largest prey item consumed by each specimen from Jatapú and Manaus varied from 4.60-207.77 $\mathrm{mm}^{3}$ $($ mean $=47.86 \pm 54.23)$ and from 4.62-358.97 $\mathrm{mm}^{3}($ mean $=128.38 \pm 115.09)$, respectively.

\section{Discussion}

Rhinella proboscidea fed on a variety of invertebrates, but the abundance of ants, termites, and mites as prey in the study areas as suggests that the feeding strategy was that of active 


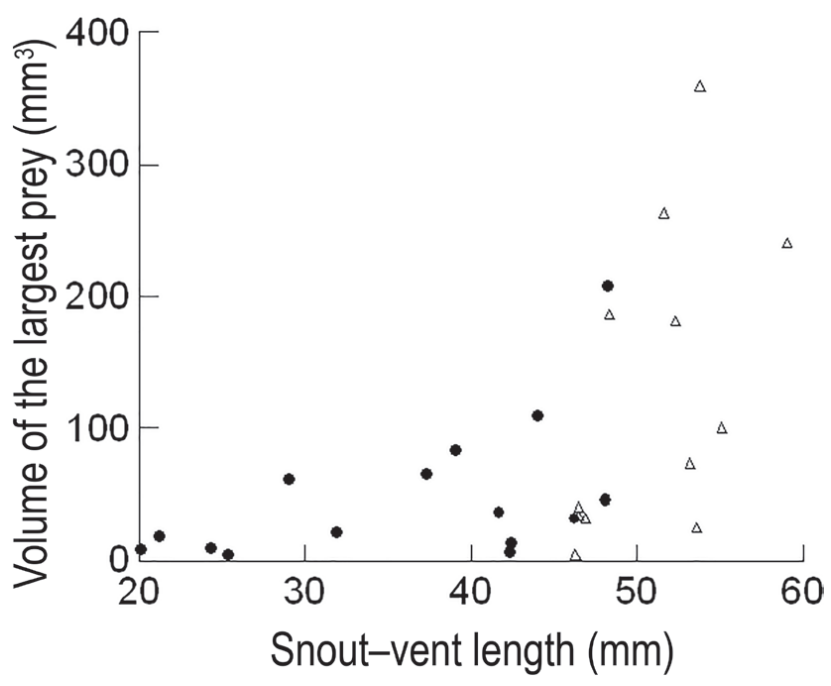

Figure 1. Relationship between the snout-vent lengths of Rhinella proboscidea and volume of the largest ingested prey in the two terra firme forests-the municipality of Manaus (open triangles) and Jatapú River (black dots) in central Amazonia, Brazil.

foragers (Toft 1980). This pattern also was observed for other species of Rhinella, as well as in other bufonids at localities across the globe (Clarke 1974, Hirai and Matsui 2002, Isacch and Barg 2002, Quiroga et al. 2009, Sabagh et al. 2012, Solé et al. 2017) and members of the neotropical $R$. margaritifera species group (Duellman 1978, Toft 1980, 1981, Parmelee 1999, Maragno and Souza 2011, FajardoMartínez et al. 2013, Astwood-Romero et al. 2016). According to Isacch and Barg (2002), bufonid species probably specialized in ant consumption because they lack teeth, which would constrain the toads to a diet of small prey.

For many species of Rhinella, beetles are the second most frequently consumed item (Duellman 1978, Toft 1980, 1981, Parmelee 1999, Isacch and Barg 2002, Quiroga et al. 2009, Maragno and Souza 2011, Sabagh et al. 2012). However, in our study areas, Isoptera (Termitidae), Acari, and Araneae were also important prey items in the diet of $R$. proboscidea. Additionally, the positive relationship that we observed between the size of toad and the size of the largest prey item consumed indicates that the size of the frog is a limiting factor in the selection of prey (Toft 1980). Eighty-three percent of the diet of smallest frogs (4 juveniles with SVLs from 20.06-25.37 mm) was composed of small Formicidae of the genera Azteca, Dolychoderus, Pheidole, and Trachymyrmex. Ontogenetic changes in the prey type corresponding to variation in body size of the toads were detected in $R$. proboscidea (Lima and Magnusson 1998) and Rhinella scitula (Caramaschi and Niemeyer, 2003) (Maragno and Souza 2011); both are members of the $R$. margaritifera species group. In our study, small prey items such as mites also were consumed by large individuals; 288 of these arachnids were found in the stomachs of only two individuals with SVLs of 52.34 and $46.51 \mathrm{~mm}$. These data agree with those of Lima (1998) in which individuals of $R$. proboscidea of different sizes consumed mites, although large individuals were able to eat other types of prey.

We found a significant difference in the trophic niche breadth of Rhinella proboscidea in the study areas; this disparity may be related to seasonal differences in the prey abundance (Burton 1976, Galatti 1992). In Manaus, all the toads were collected in June, which corresponds to the end of the rainy season and the beginning of the dry season. The toads from the Jatapú River were captured in September during the dry season. Seasonal differences in the diet composition were found in anurans of different regions (Santos et al. 2004, Maragno and Souza 2011). Alternately, the differences in the diet composition between the study could be related to local factors that affect the prey composition and abundance. The study areas (Manaus and Jatapú) are separated by about 200-215 km; thus, the detected variation should be interpreted with caution.

Ants represent $46.56 \%$ of the prey items found in the stomachs of toads, with Myrmicinae being the most typical subfamily primarily represented by the genera Crematogaster and Atta. Because of its social complexity, Myrmicinae is considered to be the most diverse group of ants. This 
subfamily also includes half of the formicid species (Bolton 1995). Crematogaster has a wide distribution in terra firme forest. These ants are generalists that can build polidomic nests with massive colonies in the leaf litter (Longino 2003). Members of the genus Atta, known as leaf-cutter ants, build complex nests with trails opening up at the soil surface (Cherrett 1968), thereby exposing them as potential prey. Some genera as Dolichoderus, Azteca (subfamily Dolichoderinae), Gnamptogenys (Ectatomminae), and Camponotus (Formicinae) are considered shrub or arboreal ants and probably were captured by Rhinella proboscidea because these ants typically do their forage on the soil (Baccaro et al. 2015).

Nematodes are common parasites found in the lungs, stomachs, and intestines of anurans, such as Rhinella marina (Linnaeus, 1758), $R$. margaritifera (Laurenti, 1768), and R. icterica (Spix, 1824) (Bursey et al. 2001, Goldberg et al. 2009, Pinhão et al. 2009). We considered the nematodes found in the stomachs of $R$. proboscidea as potential parasites. Other studies have found mainly encysted nematode larva in the stomach of anurans (Goldberg et al. 2009, Pinhão et al. 2009); thus, the presence of unencysted forms in the stomachs of $R$. proboscidea deserves additional attention.

\section{Acknowledgments}

Funding for sampling at the sites of Jatapú River was provided by the SISBIOTA Program (Ministério da Ciência, Tecnologia, Inovações e Comunicações / Conselho Nacional de Desenvolvimento Científico e Tecnológico-CNPq [\# 563348/2010] and Fundação de Amparo à Pesquisa do Estado do Amazonas-FAPEAM [Edital FAPEAM/SISBIOTA]). Maria Isabel da Silva and Linda Trueb reviewed the English usage in the manuscript. The study was supported by a fellowship from CNPq to ACRB (\# 405640/20161) and a research productivity grant to $\mathrm{MM}$. Collection of the material was authorized by the Instituto Chico Mendes de Conservação da Biodiversidade/SISBIO (\# 11323).

\section{References}

Astwood-Romero, J. A., N. Álvarez-Perdomo, M. F. ParraTorres, J. I. Rojas-Peña, M. T. Nieto-Vera, and M. C. Ardila-Robayo. 2016. Contenidos estomacales de especies de anuros em reservas naturales del municipio de Villavicencio, Meta, Colombia. Caldasia 38: 165181 .

Baccaro, F. B., R. M. Feitosa, F. Fernandez, I. O. Fernandes, T. J. Izzo, J. L. P. de Souza, and R. Solar. 2015. Guia para os Gêneros de Formigas do Brasil. Manaus. Editora INPA. 388 pp.

Batista, R. C., C. B. De-Carvalho, E. B. Freitas, S. C. Franco, C. C. Batista, W. A. Coelho, and R. G. Faria. 2011. Diet of Rhinella schneideri (Werner, 1894) (Anura: Bufonidae) in the Cerrado, Central Brazil. Herpetology Notes 4: 17-21.

Bolton, B. 1995. A taxonomic and zoogeographical census of the extant ant taxa (Hymenoptera: Formicidae). Journal of Natural History 29: 1037-1056.

Bursey, C. R., S. R. Goldberg, and J. R. Parmelee. 2001. Gastrointestinal helminths of 51 species of anurans from Reserva Cuzco Amazónico, Peru. Comparative Parasitology 68: 21-35.

Burton, T. M. 1976. An analysis of feeding ecology of the salamanders (Amphibia, Urodela) of the Hubbard Brook Experimental Forest, New Hampshire. Journal of Herpetology 10: 187-204.

Cherrett, J. M. 1968. The foraging behaviour of Atta cephalotes L. (Hymenoptera: Formicidae). Journal of Animal Ecology 37: 387-403.

Clarke, R. D. 1974. Food habits of toads, genus Bufo (Amphibia: Bufonidae). American Midland Naturalist 91: $140-147$.

Duellman, W. E. 1978. The biology of an Equatorial herpetofauna in Amazonia Ecuador. University of Kansas, Museum of Natural History, Miscellaneous Publication 65: 1-352.

Duellman, W. E. and L. Trueb. 1994. Biology of Amphibians. Baltimore. Johns Hopkins University Press. 670 pp.

Dunham, A. E. 1983. Realized niche overlap, resource abundance and intensity of interspecific competition. Pp. 261-280 in R. B. Huey, E. R. Pianka, and T. W. Schoener (eds.), Lizard Ecology: Studies of a Model Organism. Cambridge. Harvard University Press.

Fajardo-Martínez, X., A. Fajardo-Patiño, and V. J. de la Ossa. 2013. Hábitos alimentarios del complejo Rhinella margaritifera (Laurenti, 1768) (Amphibia: Bufonidae), 
Amazonas, Colombia. Revista Colombiana de Ciencia Animal 5: 301-312.

Frost, D. R. (ed.). 2019. Amphibian Species of the World: an Online Reference. Version 6.0 (17 January 2014). Electronic Database accessible at http://research.amnh. org/herpetology/amphibia/index.html. American Museum of Natural History, New York, USA. Captured on 08 February 2019.

Galatti, U. 1992. Population biology of the frog Leptodactylus pentadactylus in a Central Amazonian rainforest. Journal of Herpetology 26: 23-31.

Goldberg, S. R., C. R. Bursey, J. P. Caldwell, and D. B. Shepard. 2009. Gastrointestinal helminths of six sympatric species of Leptodactylus from Tocantins state, Brazil. Comparative Parasitology 76: 258-266.

Hirai, T. and M. Matsui. 2002. Feeding ecology of Bufo japonicus formosus from the Montane Region of Kyoto, Japan. Journal of Herpetology 36: 719-723.

Isacch, J. P. and M. Barg. 2002. Are bufonids toads specialized ant-feeders? A case test from the Argentinian flooding pampa. Journal of Natural History 36: 20052012.

Krebs, C. J. 1999. Ecological Methodology. $2^{\text {nd }}$ Edition. Menlo Park. Addison-Wesley Educational Publishers. 624 pp.

Lima, A. P. 1998. The effects of size on the diets of six sympatric species of postmetamorphic litter anurans in Central Amazonia. Journal of Herpetology 32: 392-399.

Lima, A. P. and W. E. Magnusson. 1998. Partitioning seasonal time: interactions among size, foraging activity and diet in leaf-litter frogs. Oecologia 116: 259-266.

Lima, A. P., W. E. Magnusson, M. Menin, L. K. Erdtmann, D. J. Rodrigues, C. Keller, and W. Hödl. 2012. Guia de Sapos da Reserva Adolpho Ducke, Amazônia Central. $2^{\text {nd }}$ Edition. Manaus. Editora INPA. 187 pp.

Longino, J. T. 2003. The Crematogaster (Hymenoptera, Formicidae, Myrmicinae) of Costa Rica. Zootaxa 151: $1-150$.

Maragno, F. P. and F. L. Souza. 2011. Diet of Rhinella scitula (Anura, Bufonidae) in the Cerrado, Brazil: the importance of seasons and body size. Revista Mexicana de Biodiversidad 82: 879-886.

Marques-Filho, A. O., M. N. G. Ribeiro, H. M. Santos, and J. M. Santos. 1981. Estudos climatológicos da Reserva Florestal Ducke, Manaus, Amazonas. IV Precipitação. Acta Amazonica 11: 759-768.

Oliveira, D. P., S. M. Souza, L. Frazão, A. P. Almeida, and T. Hrbek. 2014. Lizards from central Jatapú River, Amazonas, Brazil. Check List 10: 46-53.
Parmelee, J. R. 1999. Trophic ecology of a tropical anuran assemblage. Scientific Papers of the Natural History Museum, University of Kansas 11: 1-59.

Peel, M. C., B. L. Finlayson, and T.A. McMahon. 2007. Updated world map of the Köppen-Geiger climate classification. Hydrology and Earth System Sciences Discussions 11: 1633-1644.

Pinhão, R., A. C. Wunderlich, L. A. Anjos, and R. J. Silva. 2009. Helminths of toad Rhinella icterica (Bufonidae), from the Municipality of Botucatu, São Paulo state, Brazil. Neotropical Heminthology 3: 35-40.

Pinkas, L., M. S. Oliphant, and I. L. K. Iverson. 1971. Food habits of albacore, bluefin tuna, and bonito in Californian waters. Fish Bulletin 152: 1-105.

Quiroga, L. B., E. A. Sanabria, and J. C. Acosta. 2009. Size and sex-dependent variation in diet of Rhinella arenarum (Anura: Bufonidae) in a Wetland of San Juan, Argentina. Journal of Herpetology 43: 311-317.

Rafael, J. A., G. A. R. Melo, C. J. B. Carvalho, S. A. Casari, and R. Constantino (eds.). 2012. Insetos do Brasil: Diversidade e Taxonomia. Ribeirão Preto. Holos Editora. 810 pp.

Sabagh, L. T., A. M. P. T. Carvalho-e-Silva, and C. F. D. Rocha. 2012. Diet of the toad Rhinella icterica (Anura: Bufonidae) from Atlantic Forest Highlands of southeastern Brazil. Biota Neotropica 12: 258-262.

Santos, E. M., A. V. Almeida, and S. D. Vasconcelos. 2004. Feeding habits of six anurans (Amphibia: Anura) species in a rainforest fragment in Northeastern Brazil. Iheringia, Série Zoologia 94: 433-438.

Solé, M., M. S. Rocha, C. Decarli, C. R. Santos, and C. K. Pereira. 2017. Diet of post-metamorphic Rhinella icterica (Spix, 1824) from the Araucaria Plateau of Rio Grande do Sul, Brazil (Anura: Bufonidae). Herpetology Notes 10: 443-448.

Toft, C. A. 1980. Feeding ecology of thirteen syntopic species of anurans in a seasonal tropical environment. Oecologia 45: 131-141.

Toft, C. A. 1981. Feeding ecology of Panamanian litter anurans: patterns in diet and foraging mode. Journal of Herpetology 15: 139-144.

Triplehorn, C. A. and N. F. Johnson. 2011. Estudo dos Insetos. Tradução da $7^{a}$ Edição de Borror and Delong's Introduction on the Study of Insects. São Paulo. Cengage Learning. 809 pp.

Zar, J. H. 2010. Biostatistical Analysis. $5^{\text {th }}$ Edition. Englewood Cliffs. Prentice-Hall Pearson. 960 pp.

Editor: Eduardo F. Schaefer 